\title{
Tolerance of Kleingrass to Herbicides
}

\author{
R.W. BOVEY, J.R. BAUR, AND E.C. BASHAW
}

\begin{abstract}
Herbicides propazìne, 2,4-D, dicamba, picloram, tebuthiuron, and hexazinone were applied at rates of 0.14 to $2.24 \mathrm{~kg} / \mathrm{ha}$ preand postemergence to greenhouse-grown kleingrass plants. Kleingrass was tolerant to premergence sprays up to and including $1.2 \mathrm{~kg} / \mathrm{ha}$ of propazine and $0.56 \mathrm{~kg} / \mathrm{ha}$ of $2,4-\mathrm{D}$. All other herbicides and rates were phytotoxic to emerging kleingrass. At the early postemergence stage, kleingrass tolerated rates up to and including $0.28,0.56$, and 0.56 , and $1.12 \mathrm{~kg} / \mathrm{ha}$ of picloram, 2,4-D, dicamba, and propazine, respectively; but it did not tolerate tebuthiuron or hexazinone at any rate. At the intermediate vegetative stage ( 5 to $12.5 \mathrm{~cm}$ tall), kleingrass tolerated picloram, 2,4-D, dicamba, and propazine at rates of $0.56,1.12$, and 2.24 $\mathrm{kg} / \mathrm{ha}$, respectively, without injury. Mature kleingrass tolerated higher rates of all herbicides than did earlier stages of growth.
\end{abstract}

Kleingrass (Panicum coloratum L.) is a warm-season perennial bunchgrass native to South Africa which has potential for forage production on pastures and rangelands of Texas (Holt and Bashaw 1976). Kleingrass spreads by tillers and rhizomes, is above average in protein content and digestibility, and is adapted to a wide range of soil and climatic conditions. Once established, kleingrass provides good seed, forage and hay production.

Kleingrass is easily established in early spring [1.12 to 2.24 $\mathrm{kg}$ pls (pure live seed)/ha] on weed-free, well prepared seedbeds with adequate soil moisture. However, kleingrass establishment from seed is difficult under weedy conditions since seedling growth is slow and seedlings compete poorly with other vegetation. Observations (Bovey et al. 1974) and research data (Baur et al. 1977) indicate that established kleingrass is tolerant to a number of commonly used herbicides such as $2,4-\mathrm{D}[2,4$ dichlorophenoxy) acetic acid], 2,4,5-T [2,4,5-trichlorophenoxy) acetic acid], dicamba (3,6-dichloro-o-anisic acid), and picloram (4-amino-3,5,6-trichloropicolinic acid). Good weed control, 60 to 90 days after planting, is essential for establishment of kleingrass. Few data are available on the effects of herbicides on kleingrass during germination (preemergence) and early seedling growth (postemergence).

The relative tolerance of kleingrass, Selection 75 , to various rates of 2,4-D, dicamba, picloram, propazine [2-chloro-4,-6bis (isopropyl-amino-s-triazine], tebuthiuron $[N-[(1,1-$ dime-

Authors are research agronomist, plant physiologist, and geneticist, respectively, U.S Department of Agriculture, Science and Education Administration, Federal Research, Departments of Range Science and Soil and Crop Sciences, Texas A\&M University, College Station. 77843

The research is a contribution from the U.S. Dep. Agr., Sci. and Educ. Adm., Agr. Res. and the Texas Agr. Exp. Sta., College Station. This paper reports results of research only. Mention of a pesticide in this paper does not constitute a recommendation by the U.S. Dep. Agr. nor does it imply registration under FIFRA.

Manuscript received June 18,1978 thylethyl)-1,3,4-thiadiazol-2-yl] $N, N^{\prime}$-dimethylurea] and hexazinone [3-cyclohexyl-6-dimethyl-amino)-1-methyl-1-3, 5-triazine-2,4(1H,3H0-dione] was evaluated under greenhouse conditions in order to elucidate potentially useful preemergence and postemergence herbicides and rates that should be further investigated under field conditions for rangeland and pasture renovation.

\section{Materials and Methods}

Kleingrass, Selection 75, was grown in a 1:1:1 Houston black clay: sand:peat moss mixture in the greenhouse. Twenty-five kleingrass seeds were uniformly placed in each pot and covered with $5 \mathrm{~mm}$ sand. Five to 10 plants were grown in each pot. Plants were watered daily with a sprinkler nozzle. Plants treated preemergence and early postemergence were planted in pots $9.5 \mathrm{~cm}$-diam by $5 \mathrm{~cm}$-deep; plants treated at the intermediate stage of growth were grown in pots 12.7 $\mathrm{cm}$-diam by $12.7 \mathrm{~cm}$-deep; and plants treated at the mature stage were in pots $20.3 \mathrm{~cm}$-diam by $15.2 \mathrm{~cm}$-deep. Herbicides were applied preemergence on the day of planting and postemergence when plants were about 14,45 and 90 days old. When treated, average plant heights and phenological stages were 2 to $5 \mathrm{~cm}$ ( 1 to 2 leaf); 5 to $12 \mathrm{~cm}$ (3 leaf); and 30 to $61 \mathrm{~cm}$ ( 3 to 4 leaf) for the early postemergence, intermediate and mature growth stages, respectively. At the mature stage, many plants had produced reproductive culms.

A late, mature stage (437 days old) of kleingrass, buffelgrass (Cenchrus ciliaris L.), King Ranch bluestem [Bothriochloa ischaemum (L.) var. songarica (Rupr.) Celarier \& Harlan], green sprangletop [Leptochloa dubia (H.B.K.) Nees], sideoats grama (Bouteloua curtipendula (Michx.) Torr.], common Bermudagrass [Cynodon dactylon (L.) Pers.], and plains bristlegrass (Setaria macrostachya H.B.K.) plants grown in half-liter containers was also included. Before treatment, herbage of these grasses was removed several times to a stubble height of $10 \mathrm{~cm}$ and allowed to regrow. New growth was about 3 months old when sprayed with herbicide.

Herbicides applied were the potassium salt of picloram, the alkanolamine salt of 2,4-D, the dimethylamine salt of dicamba, and wettable powders of propazine $(80 \%)$, tebuthiuron $(80 \%)$, and hexazinone $(90 \%)$. Herbicides were mixed with water and sprayed at a volume of $93.5 \mathrm{~L} / \mathrm{ha}$ at rates of $0.14,0.28,0.56,1.12$ and $2.24 \mathrm{~kg} / \mathrm{ha}$ in a laboratory spray chamber (Bouse and Bovey 1967). Five replications (pots) were used per treatment. After herbicide treatment, plants were returned to the greenhouse for observation. Herbicide injury counts were made by visually estimating percent desiccation and/or dead plants per pot. If plants showed complete desiccation, they were considered dead. Preemergence and postemergence treatments were evaluated 14 and 30 days after treatment. Intermediate and mature stages were evaluated 1 and 2 months after treatment.

All studies were conducted in the greenhouse from June to December 1977. Each portion of the study (preemergence, postemergence, 
intermediate, and mature stages) was repeated at least twice and data were pooled for presentation in this paper. Significant differences among herbicides were evaluated by analysis of variance and Duncan's multiple range tests.

\section{Results and Discussion}

\section{Preemergence Treatments}

As preemergence sprays, propazine and 2,4-D were less injurious to kleingrass then were tebuthiuron, hexazinone, dicamba, and picloram (Table 1). Desiccation with propazine at $1.12 \mathrm{~kg} / \mathrm{ha}$ or less was not significantly different than that observed with untreated plants. Desiccation with propazine applied at $2.24 \mathrm{~kg} / \mathrm{ha}$ was significantly greater than that for untreated plants, but was less injurious to kleingrass than most other herbicides and rates. Preemergence application of propazine showed the most promise for further evaluation under field conditions.

Table 1. Percent desiccation (injury) of greenhouse grown kleingrass 1 month after treatment with selected herbicides applied preemergence.'

\begin{tabular}{lcccccc}
\hline \hline & \multicolumn{7}{c}{ Rate $(\mathrm{kg} / \mathrm{ha})$} \\
\cline { 2 - 7 } & 0 & 0.14 & 0.28 & 0.56 & 1.12 & 2.24 \\
\hline Herbicide & $6 \mathrm{~b}$ & $5 \mathrm{~b}$ & $8 \mathrm{ab}$ & $6 \mathrm{~b}$ & $11 \mathrm{ab}$ & $15 \mathrm{a}$ \\
Propazine & $6 \mathrm{c}$ & $77 \mathrm{~b}$ & $76 \mathrm{~b}$ & $95 \mathrm{a}$ & $99 \mathrm{a}$ & $98 \mathrm{a}$ \\
Tebuthiuron & $6 \mathrm{~b}$ & $95 \mathrm{a}$ & $98 \mathrm{a}$ & $97 \mathrm{a}$ & $99 \mathrm{a}$ & $99 \mathrm{a}$ \\
Hexazinone & $6 \mathrm{c}$ & $32 \mathrm{bc}$ & $31 \mathrm{bc}$ & $27 \mathrm{bc}$ & $77 \mathrm{a}$ & $53 \mathrm{ab}$ \\
$2,4-D$ & $6 \mathrm{~d}$ & $34 \mathrm{c}$ & $67 \mathrm{~b}$ & $93 \mathrm{a}$ & $99 \mathrm{a}$ & $88 \mathrm{a}$ \\
Dicamba & $6 \mathrm{~d}$ & $46 \mathrm{c}$ & $74 \mathrm{~b}$ & $94 \mathrm{a}$ & $99 \mathrm{a}$ & $100 \mathrm{a}$ \\
Picloram & & & & &
\end{tabular}

1 Values in horizontal rows followed by the same letter are not different at the $5 \%$ level of significance. Each value represents 15 observations evenly distributed among three experiments.

Kleingrass tolerated rates of 2,4-D up to and including 0.56 $\mathrm{kg} / \mathrm{ha}$, but did not tolerate tebuthiuron, hexazinone, dicamba, and picloram at rates as low as $0.14 \mathrm{~kg} / \mathrm{ha}$ as preemergence sprays. Hexazinone was the most injurious to kleingrass of all herbicides tested. Tebuthiuron was also extremely injurious to germinating kleingrass. Seedling growth was also damaged by preemergence application of low rates of dicamba and picloram. Consequently, these materials would probably not be successful as preemergence treatments for kleingrass in the field.

\section{Early Postemergence}

Propazine is normally considered a preemergence herbicide, although it could be used on seedling kleingrass shortly after germination. Small kleingrass plants $(2$ to $5 \mathrm{~cm}$ tall) tolerated rates of propazine up to and including $1.12 \mathrm{~kg} / \mathrm{ha}$ without detectable injury (Table 2). Kleingrass treated early postemergence was also more resistant to dicamba and picloram than preemergence treatments and it tolerated 0.56 and 0.28

Table 2. Percent desiccation (injury) of greenhouse grown kleingrass 1 month after treatment with selected herbicides applied early postemergence. ${ }^{1}$

\begin{tabular}{lrrrrrr}
\hline & \multicolumn{7}{c}{ Rate $(\mathrm{kg} / \mathrm{ha})$} \\
\cline { 2 - 7 } Herbicide & 0 & 0.14 & 0.28 & 0.56 & 1.12 & 2.24 \\
\hline Propazine & $11 \mathrm{~b}$ & $7 \mathrm{~b}$ & $13 \mathrm{~b}$ & $14 \mathrm{~b}$ & $11 \mathrm{~b}$ & $25 \mathrm{a}$ \\
Tebuthiuron & $11 \mathrm{c}$ & $47 \mathrm{~b}$ & $88 \mathrm{a}$ & $97 \mathrm{a}$ & $100 \mathrm{a}$ & $99 \mathrm{a}$ \\
Hexazinone & $11 \mathrm{~b}$ & $93 \mathrm{a}$ & $99 \mathrm{a}$ & $100 \mathrm{a}$ & $100 \mathrm{a}$ & $100 \mathrm{a}$ \\
$2,4-D$ & $11 \mathrm{~b}$ & $14 \mathrm{~b}$ & $22 \mathrm{~b}$ & $26 \mathrm{~b}$ & $68 \mathrm{a}$ & $82 \mathrm{a}$ \\
Dicamba & $11 \mathrm{c}$ & $19 \mathrm{c}$ & $16 \mathrm{c}$ & $17 \mathrm{c}$ & $45 \mathrm{~b}$ & $71 \mathrm{a}$ \\
Picloram & $11 \mathrm{c}$ & $17 \mathrm{c}$ & $18 \mathrm{c}$ & $35 \mathrm{~b}$ & $57 \mathrm{a}$ & $71 \mathrm{a}$ \\
\hline
\end{tabular}

' Values in horizontal rows followed by the same letter are not different at the $5 \%$ level of significance. Each value represents 15 observations evenly distributed among three experiments. $\mathrm{kg} / \mathrm{ha}$, respectively, without significant injury. Kleingrass also tolerated $0.56 \mathrm{~kg} / \mathrm{ha}$ of $2,4-\mathrm{D}$ without significant injury. However, when 112 or $2.28 \mathrm{~kg} / \mathrm{ha}$ of $2,4-\mathrm{D}$, dicamba, or picloram were used, considerable plant injury occurred. Typical injury symptoms with growth-regulator type herbicides $(2,4-\mathrm{D}$, dicamba and picloram) were epinasty, swollen crowns, proliferated growth, and death of some plants, especially at the higher rates of application. Kleingrass was severely injured by all rates of tebuthiuron and hexazinone. Most plants were killed with rates as low as $0.28 \mathrm{~kg} / \mathrm{ha}$ of hexazinone and $0.56 \mathrm{~kg} / \mathrm{ha}$ of tebuthiuron. These materials should not be used on kleingrass at this early stagc.

\section{Intermediate Stage}

Most herbicides were less injurious to kleingrass at the intermediate stage than at early growth stages (Table 3 ). Tebuthiuron injured no kleingrass at $0.14 \mathrm{~kg} / \mathrm{ha}$. Propazine did not affect kleingrass at any rate at the intermediate stage of growth ( 5 to $12.5 \mathrm{~cm}$ tall). Kleingrass was not affected by rates of $1.12 \mathrm{~kg} / \mathrm{ha}$ of $2,4-\mathrm{D}$ and dicamba, and $0.56 \mathrm{~kg} / \mathrm{ha}$ of picloram. Similar rates of 2,4-D, dicamba and picloram are commonly used for weed and brush control. Hexazinone was extremely phytotoxic at all rates.

Table 3. Percent desiccation (injury) of greenhouse grown kleingrass 2 months after treatment with selected herbicides applied at an intermediate stage of growth. ${ }^{1}$

\begin{tabular}{lcccccc}
\hline & \multicolumn{7}{c}{ Rate $(\mathrm{kg} / \mathrm{ha})$} \\
\cline { 2 - 7 } Herbicide & 0 & 0.14 & 0.28 & 0.56 & 1.12 & 2.24 \\
\hline Propazine & $19 \mathrm{a}$ & $12 \mathrm{~b}$ & $12 \mathrm{~b}$ & $12 \mathrm{~b}$ & $11 \mathrm{~b}$ & $11 \mathrm{~b}$ \\
Tebuthiuron & $19 \mathrm{~d}$ & $10 \mathrm{~d}$ & $40 \mathrm{c}$ & $87 \mathrm{~b}$ & $99 \mathrm{a}$ & $100 \mathrm{a}$ \\
Hexazinone & $19 \mathrm{c}$ & $71 \mathrm{~b}$ & $99 \mathrm{a}$ & $100 \mathrm{a}$ & $100 \mathrm{a}$ & $100 \mathrm{a}$ \\
$2,4-D$ & $19 \mathrm{bc}$ & $19 \mathrm{bc}$ & $14 \mathrm{c}$ & $15 \mathrm{c}$ & $23 \mathrm{ab}$ & $29 \mathrm{a}$ \\
Dicamba & $19 \mathrm{~b}$ & $23 \mathrm{~b}$ & $12 \mathrm{~b}$ & $16 \mathrm{~b}$ & $20 \mathrm{~b}$ & $52 \mathrm{a}$ \\
Picloram & $19 \mathrm{c}$ & $19 \mathrm{c}$ & $22 \mathrm{c}$ & $30 \mathrm{c}$ & $66 \mathrm{~b}$ & $89 \mathrm{a}$ \\
\hline
\end{tabular}

1 Values in horizontal rows followed by the same letter are not different at the $5 \%$ level of significance. Each value represents 10 observations evenly distributed among two experiments.

\section{Mature Stage}

Propazine did not injure the early mature stages of kleingrass ( 30.5 to $61 \mathrm{~cm}$ tall) when applied at rates up to and including $2.28 \mathrm{~kg} / \mathrm{ha}$ (Table 4). All other herbicides caused less injury than at earlier stages of growth. Dicamba, 2,4-D, and picloram did not injure kleingrass at rates up to and including $1.12 \mathrm{~kg} / \mathrm{ha}$ and they produced only slight injury at $2.24 \mathrm{~kg} / \mathrm{ha}$. Tebuthiuron did not injure kleingrass at $0.56 \mathrm{~kg} / \mathrm{ha}$ or less. Hexazinone, however, caused considerable injury (52\% desiccation) when applied at $0.28 \mathrm{~kg} / \mathrm{ha}$ and it killed most aerial growth at rates of $0.56 \mathrm{~kg} / \mathrm{ha}$ and higher.

Table 4. Percent desiccation (injury) of greenhouse grown kleingrass 2 months after treatment with selected herbicides applied at the early mature stage of growth. ${ }^{1}$

\begin{tabular}{lcccccc}
\hline \hline & \multicolumn{7}{c}{ Rate $(\mathrm{kg} / \mathrm{ha})$} \\
\cline { 2 - 7 } Herbicide & 0 & 0.14 & 0.28 & 0.56 & 1.12 & 2.24 \\
\hline Propazine & $15 \mathrm{a}$ & $10 \mathrm{~b}$ & $9 \mathrm{~b}$ & $8 \mathrm{~b}$ & $10 \mathrm{~b}$ & $12 \mathrm{ab}$ \\
Tebuthiuron & $15 \mathrm{c}$ & $16 \mathrm{c}$ & $15 \mathrm{c}$ & $20 \mathrm{c}$ & $57 \mathrm{~b}$ & $89 \mathrm{a}$ \\
Hexazinone & $15 \mathrm{c}$ & $29 \mathrm{c}$ & $52 \mathrm{~b}$ & $99 \mathrm{a}$ & $94 \mathrm{a}$ & $99 \mathrm{a}$ \\
$2,4-D$ & $15 \mathrm{~b}$ & $19 \mathrm{ab}$ & $15 \mathrm{~b}$ & $21 \mathrm{ab}$ & $17 \mathrm{ab}$ & $24 \mathrm{a}$ \\
Dicamba & $15 \mathrm{~b}$ & $17 \mathrm{ab}$ & $15 \mathrm{~b}$ & $15 \mathrm{~b}$ & $17 \mathrm{~b}$ & $21 \mathrm{a}$ \\
Picloram & $15 \mathrm{~b}$ & $19 \mathrm{~b}$ & $16 \mathrm{~b}$ & $15 \mathrm{~b}$ & $18 \mathrm{~b}$ & $29 \mathrm{a}$ \\
\hline
\end{tabular}

1 Values in horizontal rows followed by the same letter are not different at the $5 \%$ level of significance. Each value represents 10 observations evenly distributed among two experiments. 
Table 5. Percent desiccation (injury) of seven greenhouse grown grasses 2 months after treatment with selected herbicides applied at the mature stage of growth.

\begin{tabular}{|c|c|c|c|c|c|c|c|c|}
\hline $\begin{array}{l}\text { Herbicide and } \\
\text { rate }(\mathrm{kg} / \mathrm{ha})\end{array}$ & & Kleingrass & Buffelgrass & $\begin{array}{c}\text { King Range } \\
\text { bluestem }\end{array}$ & $\begin{array}{c}\text { Green } \\
\text { sprangletop }\end{array}$ & Sideoats grama & $\begin{array}{c}\text { Common } \\
\text { Bermudagrass }\end{array}$ & $\begin{array}{c}\text { Plains } \\
\text { bristlegrass }\end{array}$ \\
\hline Tebuthiuron & $\begin{array}{l}0 \\
0.56 \\
1.12 \\
2.24\end{array}$ & $\begin{array}{l}20 \\
79 \\
68 \\
87\end{array}$ & $\begin{array}{r}25 \\
100 \\
100 \\
100\end{array}$ & $\begin{array}{r}20 \\
79 \\
92 \\
100\end{array}$ & $\begin{array}{l}40 \\
70 \\
70 \\
90\end{array}$ & $\begin{array}{l}30 \\
42 \\
30 \\
37\end{array}$ & $\begin{array}{r}30 \\
84 \\
96 \\
100\end{array}$ & $\begin{array}{l}30 \\
63 \\
74 \\
97\end{array}$ \\
\hline Hexazinone & $\begin{array}{l}0 \\
0.56 \\
1.12 \\
2.24\end{array}$ & $\begin{array}{r}20 \\
98 \\
100 \\
100\end{array}$ & $\begin{array}{r}25 \\
100 \\
100 \\
100\end{array}$ & $\begin{array}{r}20 \\
100 \\
100 \\
100\end{array}$ & $\begin{array}{r}40 \\
96 \\
100 \\
100\end{array}$ & $\begin{array}{r}30 \\
98 \\
100 \\
100\end{array}$ & $\begin{array}{r}30 \\
99 \\
100 \\
100\end{array}$ & $\begin{array}{r}30 \\
94 \\
100 \\
100\end{array}$ \\
\hline 2,4-D & $\begin{array}{l}0 \\
0.56 \\
1.12 \\
2.24\end{array}$ & $\begin{array}{l}20 \\
20 \\
20 \\
20\end{array}$ & $\begin{array}{l}25 \\
22 \\
68 \\
60\end{array}$ & $\begin{array}{l}20 \\
10 \\
30 \\
30\end{array}$ & $\begin{array}{l}40 \\
54 \\
50 \\
50\end{array}$ & $\begin{array}{l}30 \\
33 \\
40 \\
33\end{array}$ & $\begin{array}{l}30 \\
40 \\
30 \\
30\end{array}$ & $\begin{array}{l}30 \\
30 \\
30 \\
30\end{array}$ \\
\hline Dicamba & $\begin{array}{l}0 \\
0.56 \\
1.12 \\
2.24\end{array}$ & $\begin{array}{l}20 \\
20 \\
20 \\
20\end{array}$ & $\begin{array}{l}25 \\
64 \\
42 \\
56\end{array}$ & $\begin{array}{l}20 \\
20 \\
10 \\
20\end{array}$ & $\begin{array}{l}40 \\
30 \\
30 \\
38\end{array}$ & $\begin{array}{l}30 \\
30 \\
30 \\
30\end{array}$ & $\begin{array}{l}30 \\
30 \\
30 \\
30\end{array}$ & $\begin{array}{l}30 \\
30 \\
30 \\
30\end{array}$ \\
\hline Picloram & $\begin{array}{l}0 \\
0.56 \\
1.12 \\
2.24\end{array}$ & $\begin{array}{l}20 \\
30 \\
30 \\
30\end{array}$ & $\begin{array}{r}25 \\
5 \\
58 \\
92\end{array}$ & $\begin{array}{l}20 \\
30 \\
43 \\
30\end{array}$ & $\begin{array}{l}40 \\
50 \\
60 \\
72\end{array}$ & $\begin{array}{l}30 \\
65 \\
77 \\
94\end{array}$ & $\begin{array}{l}30 \\
60 \\
60 \\
83\end{array}$ & $\begin{array}{l}30 \\
58 \\
46 \\
54\end{array}$ \\
\hline
\end{tabular}

Tebuthiuron, and hexazinone, at $0.56 \mathrm{~kg} / \mathrm{ha}$, substantially injured greenhouse-grown kleingrass (79 and $98 \%$ desiccation) that was over 1 year old (Table 5). Higher rates of tebuthiuron $(1.12$ and $2.28 \mathrm{~kg} / \mathrm{ha}$ ), however, did not produce complete kill of kleingrass tissue, whereas hexazinone killed all aerial growth. The injury response of other grasses to tebuthiuron, such as buffelgrass, King Range bluestem, green sprangletop, Bermudagrass, and plains bristlegrass, were similar to that of kleingrass. However, sideoats grama resisted tebuthiuron, even at rates of $2.24 \mathrm{~kg} / \mathrm{ha}$. Hexazinone at all rates was highly injurious to all grasses. Dicamba and 2,4-D at rates as high as $2.24 \mathrm{~kg} / \mathrm{ha}$ did not appear to damage mature plants of kleingrass or other grasses included in the study. Buffelgrass, however, showed sensitivity to higher rates of both herbicides. Picloram caused no injury to kleingrass or King Range bluestem, but caused extensive desiccation of buffelgrass, green sprangletop, sideoats grama, and Bermudagrass, especially at $2.24 \mathrm{~kg} / \mathrm{ha}$.

\section{Conclusions}

Propazine shows promise as a preemergence and early postemergence treatment in kleingrass since it controls a variety of germinating broadleaf and grassy weeds with little damage to kleingrass. Tebuthiuron, hexazinone, 2,4-D, dicamba, and picloram were highly injurious to kleingrass as preemergence herbicides. At the early postemergence stage, kleingrass tolerated rates of dicamba and 2.4-D up to $0.56 \mathrm{~kg} / \mathrm{ha}$ and picloram up to $0.28 \mathrm{~kg} / \mathrm{ha}$. At the intermediate and mature stages of growth, kleingrass usually tolerated 2,4-D, dicamba, and picloram at rates of $1.12 \mathrm{~kg} / \mathrm{ha}$ or higher. Tebuthiuron and hexazinone were highly phytotoxic to kleingrass at most rates and stages of growth but have shown promise for control of smutgrass [Sporobolus poiretii (Roem. \& Schult.) Hitchc.] (Meyer and Baur 1977) and certain species of brush (Bovey et al. 1975; Nickels and Stritzke 1977). Several grasses responded similarly to kleingrass when rates of $0.56,1.12$, and $2.28 \mathrm{~kg} / \mathrm{ha}$ of tebuthiuron were used. Sideoats grama, however, was tolerant of tebuthiuron treatments. Hexazinone at 0.56 to 2.24 $\mathrm{kg} /$ ha killed most grasses. Dicamba, 2,4-D, and picloram were less injurious to most grasses as foliar sprays with the exception of buffelgrass, which showed injury only at higher rates. Picloram as a foliar spray injured most grasses at higher rates with the exception of kleingrass and King Range bluestem.

At all stages of growth, one would consider greenhousegrown plants more susceptible to herbicides than those planted in the field. Consequently, under field conditions, higher herbicide rates than those indicated in this study may be safe. Herbicides are more phytotoxic to greenhouse plants because (a) they are more succulent and leaves have less cuticle development for inhibiting herbicide absorption, (b) the plant roots and the herbicide are confined to a small volume, and (c) pots are watered daily, resulting in optimum distribution of the herbicide into the root zone of the treated plants.

\section{Literature Cited}

Baur, J.R., R.W. Bovey, and E.C. Holt. 1977. Effect of herbicides on production and protein levels in pasture grasses. Agron. J. 69:846-851.

Bouse, L.F., and R.W. Bovey. 1967. A laboratory sprayer for potted plants. Weeds 15:89-91.

Bovey, R.W., R.E. Meyer, and E.C. Holt. 1974. Tolerance of Bermudagrass to herbicides. J. Range Manage. 27:293-296.

Bovey, R.W., R.E. Meyer, and J.R. Baur. 1975. Evaluation of tebuthiuron for woody plant control. Weed Sci. Soc. Amer. Abstr. No. 54. p 22-23.

Holt, E.C., and E.C. Bashaw. 1976. Developing improved grasses and legumes. Chapter 1. p 7-9. In: Grass and Legumes in Texas, Development, Production and Utilization. E.C. Holt and R.D. Lewis (eds.). Tex. Agr. Exp. Sta., Res. Monogr. 6.

Meyer, R.E., and J.R. Baur. 1977. Control of smutgrass [Sporobolus poiretii (R. \& S.) Hitchc.]. Weed Sci. Soc. Amer., Abstr. No. 14, p 6-7.

Nickels, J.K., and J.F. Stritzke. 1977. Some potential uses of tebuthiuron and 3-cyclohexyl-6-(dimethylamino)-1-methyl-1,3,5-triazine-2,4(1 H,3H)dione in pine management. Proc. South. Weed Sci. Soc. 30:246. 